\title{
Effects of Squash Leaf Trichome Exudates and Honey on Adult Feeding, Survival, and Fecundity of the Squash Bug (Heteroptera: Coreidae) Egg Parasitoid Gryon pennsylvanicum (Hymenoptera: Scelionidae)
}

\author{
D. L. OLSON AND J. R. NECHOLS \\ Department of Entomology, Kansas State University, Manhattan, KS 66506
}

\begin{abstract}
Environ. Entomol. 24(2): 454-458 (1995)
ABSTRACT A laboratory cxperiment was conducted to determine whether leaf cxudates could be used as a source of adult nutrition for the squash bug, Anasa tristis (De Geer), egg parasitoid, Gryon pennsylvanicum (Ashmead), and to compare adult and progeny fitness traits when female wisps were provided with squash leaves, a standard honey diet, a combination of leaves and honey, or water only. Results showed that fecumdity, progeny developmental rates, and progeny survival did not differ significantly when females were exposed to different dietary sources. Adult longevity was shorter on squash leaves without honey than on leaves with honey ar the honey-only diet. However, reproductive fitness was not reduced because oviposition had been completed before death of the adult females. When only water was provided, parasitoid females lived only a few days. Observations showed that squash leaves have two kinds of trichomes (hair-like and peg-like), both of which produce droplets that are fed on by both sexes of $G$. pennsylvanicum. Nutrient analyses revealed that exudates from the? hair-like trichomes are composed predominantly of monosaccharides (mainly glucose and galactose), and that the peg-like trichomes produce glucose and some protein. Thus, these trichomes appear to serve as extrafloral nectaries and may provide an important encrgy source for augmentatively released $G$. pennsylvanicum.
\end{abstract}

KEY WORDS Cryon pennsylvanicum, egg parasitoid, adult diet

MOST PARASITOIDS REQUIRE food during at least part of their adult life. Therefore, availability of adult food, either for protein or as an energy source, may significantly increase the successful use of parasitoids in biological control programs (Leius 1960; Rogers 1985; Hagen 1986; Jervis et al. 1992, 1993). Common food sources include host insects (i.e., host feeding), honeydew, and pollen and nectar associated with flowers. Another less well documented, but important, food resource used by parasitoids and other insects is extrafloral nectaries (Atsatt \& O'Dowd 1976, Keeler 1978, Hagen 1986). Extrafloral nectaries are specialized glandular tissues or organs that occur on vegetative structures of plants (Fahn 1979, Elias 1983). These nectaries have been shown to contain mono- and disaccharides, amino acids, proteins, or trace amounts of other compounds (Bentley 1977, Baker et al. 1978, Elias 1983, Hagen 1986). The presence or absence of extrafloral nectaries has been shown to affect both reproduction (Treacy et al. 1987) and longevity (Putman 1963, Lingren \& Lukefahr 1977) of parasitoids.

Gryon pennsylvanicum (Ashmead), a naturally occurring egg parasitoid of the squash bug, Anasa tristis (De Geer), is a candidate for angmentative releases to control this serious pest (Nechols et al.
1989). Bectuse this parasitoid does not host-feed (Vogt \& Nechols 1993), and because carly-season releases of this parasitoid may be required (i.e., before flowers or other food sources are present), we speculated that adult food may be a limiting factor. However, a detailed inspection of our squash and pumpkins cultivars revealed that the lower leaf surfaces bear two kinds of trichomes, which appear to fit the description of extrafloral nectaries. Therefore, our objectives were the following: (1) to compare adult longevity and fecundity, and progeny survival, development and sex ratio of $G$. pennsylvanicum on squash leaves and a standard diet (honey), (2) establish whether $G$. pennsylvanicum adults feed on exudates from the nectary-like trichomes, and (3) determine the nutrient composition of these exudates.

\section{Materials and Methods}

Effects of Adult Food Source on Reproduetion, Longevity, Progeny Development, Survival, and Sex Ratio. To determine the effects of different food sources on the biology of G. pennsylvanicum, 1-d-old mated females from a 1992 laboratory colony were exposed individually either to honey, a squash leaf, or a squash leaf plus honey. 
The experimental arena consisted of a cardboard container $(12.7$ by $15.2 \mathrm{~cm})$ covered with an orgaundy mesh top. All containers were maintained in in civirommental growth chamber at $27 \pm 0.5^{\circ} \mathrm{C}$ it photoperiod of $14: 10$ (L:D) h, and $\approx 70 \% \mathrm{RH}$. In the leaf treatments, individual squash leaves, Cucurbita pepo L. 'Early Prolific Straightneck', were excised from insect-free, greenhouse-grown plants in the 4- to 6-leaf stage. The petiole was immediately inserted into a florist's water pick which was passed through a $1.25 \mathrm{~cm}$ diameter hole in the sicle of the container. Observations indicated that excised leaves continued to exude droplets. In the honey treatments, a honey-dotted index card $(1.2$ by $4.0 \mathrm{~cm}$ ) was placed in the container. In all treatments, water was supplied by inserting a vial of distilled water, sealed with cotton, through a second hole in the container. A container with a water vial but no food source served as the control. The experiment was set up as a completely randomized design and was run on two different dates. On each date, five different females were te'sted per treatment.

Daily, for a maximum of $22 \mathrm{~d}$, parasitoids were provisioned with 1-d-old squash bug eggs for $24 \mathrm{~h}$ according to the following schedule: 18 eggs on days 1-3, 8 eggs on days $4-7$, and 3 eggs on days 8-22. This allocation of host eggs is based on the oviposition schedule of G. pennsylvanicum reportad by Nechols et al. (1989). One day before exposure to parasitoids, newly oviposited squash bug e'ggs were rinsed with distilled water to remove any water-soluble squash bug contaminants. Eggs then were glued to a piece of index card using a small dot of white glue. Squash bug eggs were removed daily, placed in labeled shell vials and held in an cnvirommental chamber under the conditions described above.

longevity and fecundity data were recorded for each female. We estimated longevity by the number of days adult females lived up to a maximum of $22 \mathrm{~d}$, which is the average reproductive lifespan of (x. pennsyluanicum (Vogt \& Nechols 1993). Fecundity was estimated by recording the total number of squish bug eggs parasitized per female over the entire reproductive period.

To assess possible indirect effects of adult diet on progeny fitness, squash bug eggs were examined daily beginning $17 \mathrm{~d}$ after exposure for wasp cmergence. Five days after emergence began, all umeclosed squash bug eggs were dissected and catcgorized by developmental stage for both parasitized and imparasitized eggs. For each day that femiales successfully oviposited (hereafter femaleday), the percentage of surviral was computed by dividing the number of progeny that successfully emerged into the number of parasitized hosts and multiplying by 100. Percentages of female and male emergence also were computed. In addition, parasitoid total developmental time (from oviposition to adult emergence) was recorded.
Data were analyzed using an analysis of variance (PROC ANOVA) (SAS Institute 1990) with test date serving as a block. The analysis showed no significant block effect. Therefore, the datal for each biological characteristic were pooled for all 10 females before analysis. A general linear model (PROC GLM) was used to determine the least significant difference (LSD) of means at the $P \leq 0.05$ level (SAS Institute 1990). Voucher specimens of G. pennsyluanicum have been deposited under lot number 053 in the Entomology Research Collection at Kansas State University in Manhattan.

Feeding Behavior. Both sexes of G. pennsylvanicum were observed for evidence of feeding on different anatomical structures of squash leaves. To make detailed observations of adult wasp feeding behavior, the petiole of an intact squash leaf was inserted into a florist's water pick. The leaf was placed upper (adaxial) surface down on the stage of a stereomicroscope. Individual fernale or male parasitoids, unfed for $24 \mathrm{~h}$, were placed on the exposed lower leaf surface and allowed to move freely for up to $15 \mathrm{~min}$. Feeding behavior was videotaped for $\approx 10$ adults (mixed sexes) using a Javelin (Model JE3462HR, Chromachip II, Tarrance, CA) video camera attached to an Olympus (Modcl SZ4045TR, CTV, Lake Success, NY) steremicroscope and linked to a TV monitor and VCR. Parasitoids that did not initiate feeding within $5 \mathrm{~min}$ of placement on the leaf, or did not resume feeding within $5 \mathrm{~min}$ of ending a feeding bout, were replaced. All observations were made between 0600 and 0900 hours CST

Trichome Nutrient Analysis. Hair-like and peglike trichomes were manually removed from dricd squash leaves. The exudates of the peg-like trichomes were dissolved in distilled water, and the trichomes were discarded. The hair-like trichomes were left intact. The samples were maintained on ice to prevent the development of bacteria until they were analyzed. Gas-liquid chromatography was used to analyze the hair-like trichomes and the dissolved exudates of the peg-like trichomes for carbohydrates (mono- and disaccharides) (Mawhinney et al. 1.980, Mawhinney 1986). The peglike trichomes also were analyzed for protcin using the analysis of nitrogen by combustion method (Association of Official Analytical Chemists 1990). Analyses were done by Thomas Mawhinney, Experimental Station Chemical Laboratories, University of Missouri, Columbia, MO.

\section{Results}

Effect of Adult Food Source on Reproduction, Longevity, Progeny Development, Survival, and Sex Ratio. Neither the oviposition pattem nor fecundity differed significantly among $G$. pennsylvanicum females that were provided with different food sources. However, significantly fewer eggs were laid when wasps were provided with water only (Table 1). Longevity also was signifi- 
Table 1. Mean feeundity and longevity of female Gryon pennsylvanicum when maintained on different diets

\begin{tabular}{lcr}
\hline Treatment & $\begin{array}{c}\text { Mean no. } \\
\text { eggs } \pm S E M\end{array}$ & $\begin{array}{r}\text { Mean no. days } \\
\text { lived } \pm \text { SEM }\end{array}$ \\
\hline Water only & $23.0 \pm 5.63 \mathrm{a}$ & $2.5 \pm 1.0 \mathrm{a}$ \\
Squash leaf & $72.9 \pm 5.63 \mathrm{~b}$ & $17.1 \pm 1.08 \mathrm{~b}$ \\
Squash leaf + honey & $72.4 \pm 5.63 \mathrm{~b}$ & $22.0 \pm 1.0 \mathrm{Sc}$ \\
Honey & $79.1 \pm 5.63 \mathrm{~b}$ & $21.7 \pm 1.0 \mathrm{Sc}$ \\
\hline
\end{tabular}

Means within a column followed by the sime letter are not significantly different ( $P \leq 0.05$; I.SMEANS, SAS Institute 1990) There were 10 mated fomales in each troatment. Water was present in all treatments. SEMs pooled from ANOVA.

cantly shorter when only water was available than when food sources were provided (Table 1). Females provisioned with a squash leaf lived significantly fewer days than females that were provided with honey or a squash leaf plus honey.

The percentage of $G$. pennsylvanicum progeny that emerged did not differ significantly among adult females provisioned with water only or different food sources (Table 2). The percentages of female and male $G$. pennsylvanicum that emerged also did not differ significantly $(P>0.05)$ among adult food sources or the water control. In addition, the total developmental period of progeny was similar for adult females provisioned with different diets or water (Table 2). No statistical differences in progeny emergence or developmental time were observed throughout the oviposition period.

Feeding Behavior. G. pennsylvanicum females and males fed on both kinds of trichomes present on squash leaves. Hair-like trichomes, which cover the entire lower leaf surface, were found to have a minute drop of exudate attached to the tip (Fig. 1A). Peg-like trichomes occur less frequently than hair-like trichomes and are scattered at random on the underside of leaves (Fig. 1B). The top of the peg-like trichome forms a concave bowl that holds a droplet of viscous fluid.

Table 2. Mean percentuge progeny survival and number of days for total development (cgg to adult) when Gryon pennsylvanicum adult females were maintained on different diets

\begin{tabular}{|c|c|c|c|}
\hline Treatment & $n$ & $\begin{array}{l}\text { Mean \% } \\
\text { progeny } \\
\text { survival } \\
\pm \text { SEM }\end{array}$ & $\begin{array}{l}\text { Mean no. } \\
\text { days for } \\
\text { development } \\
\text { = SEM }\end{array}$ \\
\hline Water only & 21 & $90.1 \pm 5.6 \mathrm{a}$ & $18.2 \pm 0.28 \mathrm{a}$ \\
\hline $\begin{array}{l}\text { Squash leat } \\
+ \text { honey }\end{array}$ & 131 & $95.7 \pm 2.2 \mathrm{a}$ & $18.4 \pm 0.11 \mathrm{a}$ \\
\hline Squash lcaf & 111 & $95.6 \pm 2.6 \mathrm{a}$ & $18.5 \pm 0.12 \mathrm{a}$ \\
\hline Hontey & 141 & $95.4 \pm 2.3 a$ & $18.1 \pm 0.11 \mathrm{a}$ \\
\hline
\end{tabular}

Water was present in all treatments. There were 10 mated females in each treatment. Means within columns followed by the same letter are not significantly different $(P \leq 0.05$; LSMEANS SAS Institute, 1990). N, mumber of female-davs; number of ovipositing females times number of oviposition days (ramge of parasitized (eggs: 3-1s).
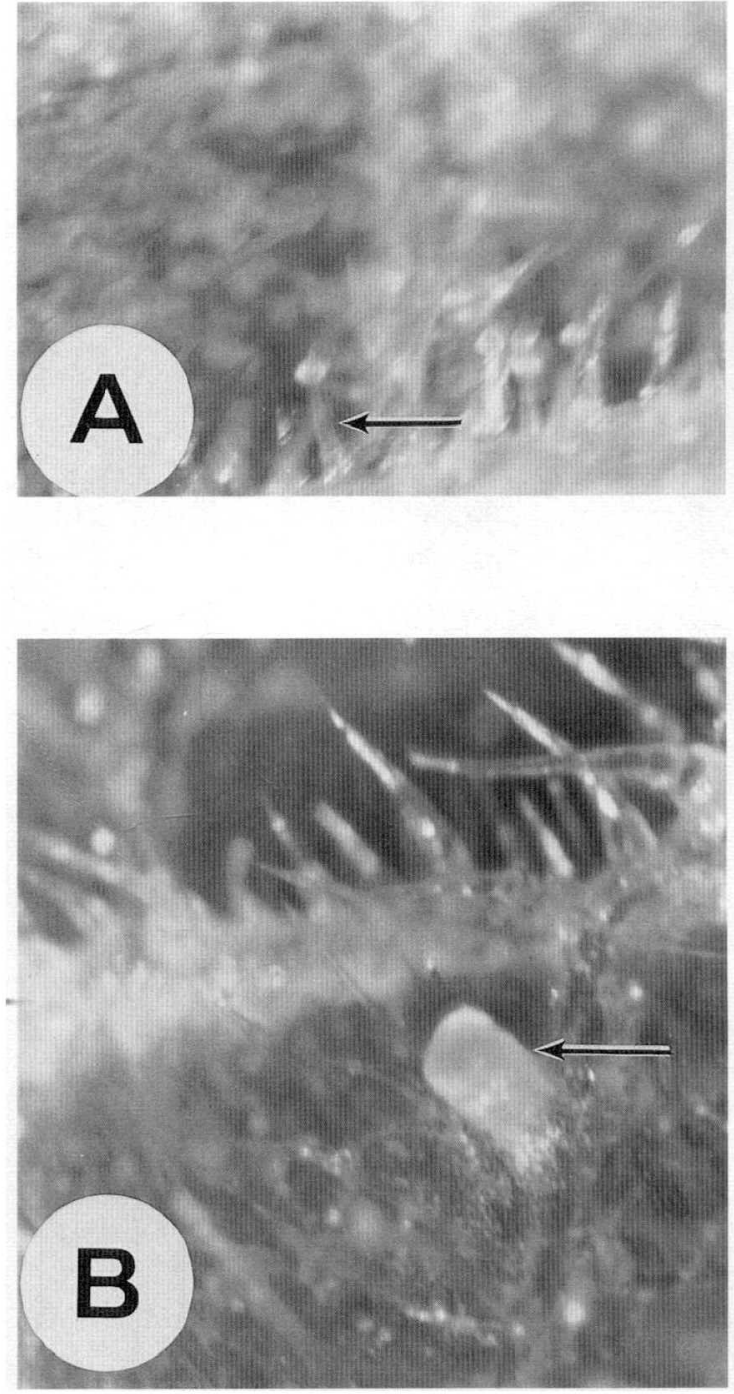

Fig. 1. Trichomes present on the lower leaf surface of squash (Cucurbita pepo L. 'Early Prolific Straightneck'). (A) Hairlike trichomes. (B) Prglike trichome.

Trichome Nutrient Analysis. The mutrient composition of the hair-like trichomes includes a complex of four monosaccharic!es. Galactose and glucose are present at substantially higher levels (15.5 and $12.3 \mu \mathrm{g} / \mathrm{mg}$ dry iveight sample, respectively) than mannose and $\mathrm{N}$-glucosamine (Table 3 ). In the peg-like trichomes, glucose was the only sugar detected (Table 3 ). Protein also was present, but at lower concentrations than glucose. Hair-like trichomes were not analyzed for protein or other possible nutrients.

\section{Discussion}

Most studies of extrafloral necturies have examined either entomophagous insect behavior, their effect on natural enemies, or their amatomy and 
Tuble 3. Sipuash leaf trichome exudate nutrient analysis

\begin{tabular}{|c|c|c|}
\hline Nutrient & $\begin{array}{l}\text { Hair-like } \\
\text { trichomess }\end{array}$ & $\begin{array}{l}\text { Pegr-like } \\
\text { trichoones, }\end{array}$ \\
\hline Gialactose' & 15.5 & NI) \\
\hline Calucenser & 12.3 & 67.8 \\
\hline Nitmorose & 1.9 & ND \\
\hline N-alcety-ghlucostmine & 0.6 & ND \\
\hline Proteriil & w: $:$ : & 14.5 \\
\hline
\end{tabular}

*:st: monedetectalsle ancounts of mutrients.

"Nintrients ane recorded as $\mu \mathrm{d} / \mathrm{mg}$ of sample, dry weight basis.

b Nitritents une recorded as $\mu \mathrm{g} / \mathcal{O}(0) \mu \mathrm{l}$ of sample, set weight basis.

mutrient composition (see references cited in introduction and below). Our research is somewhat minique in that it links G. pomsylvanicum feeding behatior on specific squash leaf microstructures with rological evidence that those leaves serve as a source of nutrition for this parasitoid. In addition, we show that these trichomes produce simple sugars, particularly glucose, which may serve as commom mutricnts for parasitoids. Based on these collective data, we conclude that both hair-like and perg-like trichomes sene as extrafloral nectaries for (x. pennsylennicum.

Our studics iuvolved one cultivar of squash, $\mathrm{Cu}$ curbita pepo I. 'Early Prolific Straightneck'. How"wor, there is evidence that extrafloral nectaries are common within the Cucurbitaceae. For example, Pinberton (1990) found extrafloral nectaries in five other cucurbitaceous species in Korea. Extrafloral nectaries occur in many species of $\approx 70$ families across a wide variety of plant taxa found in the tropical and temperate regions (Bentley 1977, Baker et al. 1978, Elias 1983, Pemberton 1988, 1990). Fistrafloral nectaries may have evolved as defensive structures for plants. In exchange for providing carbohydrates and amino acids, which attract and nomrisli parasitoids and predators (especially ants), nitural enemies may provide a long-term (i.e., evoIntionary) bonefit to plants by reducing damage caused in insect herbivores (Baker et al. 1978, Price et al. 1980, Pemberton 1990, 1992, Jervis et al. 1992).

Protcin is present in at least one of the two types of extrafloral nectaries we investigated. However, extensive studies of $G$. pennsylvanicum suggest that this parasitoid does not require an exogenous somre of protein as an adult to reproduce (Vogt \& Nechols 1993). In fact, with very few exceptions (Clausen 1940, Bin 1985), scelionids do not hostfered or recpuire adult food other than a carbohydrate source to reproduce (see review by Orr 1988 and papers cited therein). Our observation that fecuundity did not differ among food sources appears to confirm these previous findings. Our experiment does indicate that sugars are important energy sources for $G$. pennsylicanicum, and that they affect the length of their reproductive life. For reasons we do not know, females provided with a squash leaf only during their ovipositional period lived an average of only $17 \mathrm{~d}$ as compared with 22 $\mathrm{d}$ on honey or a squash leaf plus honey diet. Some insects cannot utilize galactose, mannose or $\mathrm{N}$-acetyl-glucosamine as energy substrates (Chippendale 1978). Therefore, the amount of glucose present in the trichomes may have been suboptimal for $C$. pennsylvanicum. However, the significantly shorter longevity did not affect fecundity because most parasitoid eggs were deposited during the first 2 wk. This oviposition pattern is consistent with that reported by Nechols et al. (1989).

Extrafloral nectaries have been shown to affect the longevity of other parasitoids. The braconid Campoletis sonorensis (Boddie) and the trichogrammatid Trichogramma pretiosum (Riley), which commonly parasitize tobacco budworms and bollworms in cotton fields, respectively, lived significantly longer on nectaried cotton strains than on nectariless cotton (Lingren \& Lukefahr 1977, Treacy et al. 1987). Macrocentrus ancylivorus (Roh.), a braconid parasitoid of the oriental fruit moth, lived almost $1 \mathrm{wk}$ longer when provisioned with active nectaries on peach leaves than whon nectaries were inactive (Putman 1963).

The source of adult food also has been shown to be an important factor for the production of parasitoid progeny. Trichogramma spp. and C. sonorensis progeny emergence was higher from bollworm eggs and tobacco budworm larvae, respectively, when collected on nectaried cotton strains than on nectariless cotton (Lingren \& Lukefahr 1977, Treacy et al. 1987). In addition, parasitism of tent caterpillar eggs and pupae, and codling moth larvae, was higher when these herbivorous hosts occurred in apple orchards that contained an undergrowth with an abundance of nectar-producing flowers (Leius 1967). However, our experiment suggests that adult nutritional sources, including squash leaf extrafloral nectaries, do not influence? progeny fitness in $G$. pennsyluanicum. The percentage of progeny that emerged, and their developmental times and sex ratios were similar among treatments and throughout the entire ovipositional period. The developmental time of $\approx 18 \mathrm{~d}$ is typical of $G$. pennsylvanicum that are reared under artificial conditions where they are provided with only honey and water.

The implications of squash leaf extrafforal nectaries for biological control are 3 -fold. The natural presence of extrafloral nectaries in a squash or pumpkin field may be important for the conservation of $G$. pennsylvanicum, in addition to providing a cost-free source of adult food. Also, recent field and economic analyses suggest that biological control may be more cost-effective, and have a greater impact, if active releases of $G$. pennsylvanicum are made in combination with squash bugresistant cultivars (D.L.O., unpublished data). Therefore, when selecting cucurbit cultivars for squash bug resistance, care should be taken not to select against extrafloral nectaries. 


\section{Acknowledgments}

We thank T. L. Hopkins and J. C. Reese (Kansas State University) for reviewing an earlier version of this manuscript. We thank T. L. Hopkins for advice conceming extraction of trichome exudates and T. Mawhinney (University of Missouri) for chemical analyses. We appreciate the technical assistance provided by $\mathrm{C}$. Leaming and $\mathrm{E}$. Vogt (Kansas State University). This is contribution number 94-497-J from the Kansas Agricultural Experiment Station.

\section{References Cited}

Associution of Official Analytical Chemists. 1990. Of ficial methods of analysis, vol. 15, Sec. 990.03. Association of Official Analytical Chemists, Arlington, V'A.

Atsatt, P. R. \& D. J. O'Dowd. 1976. Plant defernse guilds. Science (Washington, DC) 193: 24-29.

Baker, H. G., P. A. Opler \& I. Baker. 1978. A comparison of the amino acid complements of floral and extrafloral nectars. Bot. Gaz. 139: 322-332.

Bentley, B. L. 1977. Extrafloral nectaries and protection by pugnacious bodyguards. Ammu. Rev. Ecol. Syst. S: $407-427$

Bin, F. 1985. Phoresy in an egg parasitoid: Mantibarid sacfelderiana (De Stef.-Per) (Hym. Scelionidae), pp. 901-902. In Atti XIV Congresso Nazionale Italiano di Entomologia sotto gli auspici dell'Accademia Nazionale Italiano di Entomologia, della Societa Entomologica Italiana e della Intermational Union of Biological Sciences. Accademia Nazionale Italiana di Entomologia, Palermo, Italy (in Rev. Appl. Entomol 1986, 74: 320).

Chippendale, G. M. 1978. The functions of carbolyydrates in insect life processes, pp. 1-54. In M. Rockstein [ed.], Biochemistry of insects. Academic, New York.

Clausen, C. P. 1940. Entomophagous insects. McGraw-Hill, New York.

Elias, T. S. 1983. Extrafloral nectaries: their structure and distribution, pp. 174-204. In B. Bentley \& T. Eijas [eds.], The biology of nectaries. Columbia University Press, New York.

Falu, A. 1979. Ultrastructure of nectaries in relation to nectar secretion. Am. J. Bot. 66: 977-985

Hagen, K. S. 1986. Ecosystem analysis: plant cultivars (HPR), entomophagous species and food supplements, pp. 151-197. In D. J. Boethel \& R. D. Eikenbary [eds.], Interactions of plant resistance and parasitoids and prodators of insects. Wiley, New York

Jervis, M. A., N.A.C. Kidd \& M. Walton. 1992. A review of methods for determining dietary range in adult parasitoids. Entomophaga 37: 565-574.

Jervis, M. A., N.A.C. Kidd, M. G. Fitton., T. Huddleston \& H. A. Dawah. 1993. Flower-visiting by hymenopteran parasitoids. ]. Nat. Hist. 27: 67-105.

Keeler, K. H. 1978. Insects feeding at extrafloral nectaries of Ipomoca carmea (Convolulaceate). Entomol. News, 89: 163-168.
Leius, K. 1960. Attractiveness of different foods and flowers to the adults of some lymenopterous parasites. Can. Entomol. 92: 369-376.

1967. Influence of wild flowers on parasitism of tent caterpilliar and codling moth. Can. Eutomol. 99: 444446.

Lingren, P. D. \& M. J. Lukefahr. 1977. Effects of nectariless cotton on caged populations of Campolet is sonorensis. Environ. Entomol. 6: 586-588.

Mawhinney, T. P. 1986. The simultameous determination of $\mathrm{N}$-acetylglucosamine, $\mathrm{N}$-acetylgalactosanine, $\mathrm{N}$-acetylglucosiminitol and $\mathrm{N}$-acetylgal actosaminitol by gas-liquid chromatography. J. Chromatogr. 35 1: $91-102$.

Mawhinney, T. P., M. S. Feather, G. J. Barbero \& J. R. Martinez. 1980. The rapid, quantitative detesmination of neutral sugars (as aldononitrile acetates and anino sugars (as O-methyl-oxime acestates) in glycoproteins by gas-liquid clıromatography. Anal. Biochem. 101: 112-117.

Nechols, J. R., J. L. Truey \& E. A. Vogt. 1989. Conparative ecological studies of indigenous egg parasitaids (Hymenoptera: Scelionidae; Encyrtidae) of the squash bug, Anasa tristis (Hemiptera: Coreidae). I. Kins. Entomol. Soc. 62: 177-188.

Orr, D. B. 1988. Scelionid wasps as biological control agents: a review. Fla. Entomol. 71: 506-52S

Pemberton, R. W. 1988. The abundance of plants bearing extrafloral nectaries in Colorado and Mojave desert communities of southem California. Madrono 35: $238-246$.

1990. The accurrence of extrafforal nectaries in Korean plants. Koreanl J. Ecol. 13: 251-266.

1992. Fossil extrafloral nectaries, evidence for the antguard antiherbivore defense in an oligoceme Populus. Am. J. Bot. 79: 1242-1246.

Price, W. P., C. E. Bouton, P. Gross, B. A. MePheron, J. N. Thompson \& A. E. Weis. 1980. Interactions among threc troplic levels: Influence of plants on interactions between insect herbivores and natural enemies. Ammu. Rev. Ecol. Syst. 11: 41-65.

Putman, W. L. 1963. Nectar of peach leaf glands as insect food. Cin. Entomol. 95: 108-109.

Rogers, C. E. 1985. Extrafloral nectar: entomological implications. Bull. Entomol. Soc. Am. 3: 15-20.

SA S Inslitule. 1990. SAS/SAT user's guide, version 6 4th ed., vol. 2. SAS Institute, Cary, NC.

Treacy, M. F., J. H. Benedict, M. H. Wulmsley, J. D. Lopez \& R. K. Morrison. 1987. Parasitisin of bollworm (Lepidoptera: Noctuidae) eggs on nectaried and nectariless cotton. Environ. Entomol. 16: 420-423.

Vogt, E. A. \& J. R. Nechols. 1993. Responses of the? squash bug (Hemiptera: Coreidae) and its egg parasitoid Gryon pennsyltanicum (Hymenoptera: Scelionidae) to three Cucurbita cultivars. Environ. Entomol. 22: $238-245$.

Received for publication 19 May 1994; accepted $1 \mathrm{No}$ vember 1994 